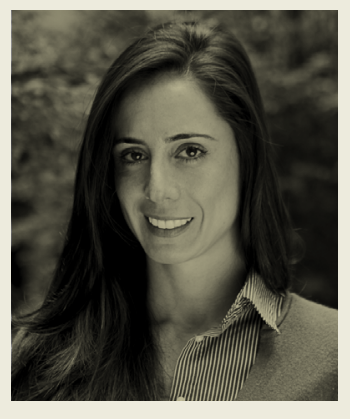

\title{
COMPLIANCE COMO DIFERENCIAL COMPETITIVO
}

A maior parte adulta de nosso país foi criada em um ambiente em que afirmações como "políticos são assim mesmo", "rouba, mas faz" e "rico não vai para cadeia" eram não só comuns como de aceitação quase osmótica. O mais chocante é que tais frases normalmente eram ditas por uma maioria honesta, trabalhadora e cumpridora de suas obrigações.

Nos últimos anos, esse cenário vem mudando. Tanto nas mesas de reuniões das grandes e pequenas empresas quanto nos jantares em família, todos estão discutindo ética, conduta e reputação. Compliance, um termo antes restrito ao universo corporativo, vem ganhando notoriedade.

De forma resumida, compliance é um pilar da governança corporativa. A área inclui, entre outras responsabilidades, assegurar uma atuação ética e responsável e o cumprimento de regulamentos estabelecidos pela organização, por entidades setoriais, por órgãos reguladores e pela legislação de modo geral.

Há não muito tempo, era necessário grande esforço para incluir nas agendas das empresas discussões sobre conformidade e comportamento ético. Mais difícil ainda era fazer com que as corporações incorporassem esses temas em seu planejamento estratégico. Agora, a rota inverteu-se. É o alto escalão das organizações que demanda um programa efetivo de compliance e se envolve diretamente em sua implementação, atitude fundamental para impactar a cultura organizacional.

Um item essencial de qualquer programa de compliance é não só a disseminação de pressupostos de boa conduta e cumprimento da legislação, mas também o efetivo treinamento dos seus colaboradores, de forma abrangente e aprofundada. O objetivo deve ser ampliar e fortalecer a cultura de empoderamento individual, apurando um senso de autonomia e responsabilidade diante de questões éticas do dia a dia. As organizações precisam contribuir para o desenvolvimento de seus colaboradores, de maneira complementar à formação pessoal e acadêmica.

Porém a prática mostra que falar, ainda que ostensivamente, sobre ética e conduta só faz sentido se as pessoas conseguem enxergar a teoria refletida no padrão comportamental de sua liderança. Ou seja, é preciso comprometimento dos dirigentes e, mais que isso, eles devem se tornar referência na conduta esperada de todos os funcionários - o chamado walk the talk.

Compliance ganhou espaço na agenda. Acredito que passamos a ser uma importante ferramenta de engajamento, incentivo ao comprometimento com a ética no Brasil e fator de alavancagem reputacional. Tenho lido e ouvido de líderes diversos que não se pode cobrar ou admitir resultados a qualquer preço. O avanço é inegável. Ganham diferencial competitivo as corporações transparentes e que apresentam mecanismos de controle interno. São empresas voltadas para uma cultura ética, $100 \%$ alinhadas aos valores, à missão e ao propósito, em que os executivos não são avaliados apenas por resultados financeiros.

Há ainda muito espaço para o desenvolvimento da área no Brasil. É preciso combater incansavelmente a cultura de banalização de infrações éticas e da impunidade, tão enraizada no "inconsciente consciente" coletivo. É necessário investir tempo e esforços em disseminar a máxima de que é perfeitamente possível ser exitoso no Brasil, fazendo o que é certo, transpirando conceitos de boa conduta. 